\title{
Water in the critical zone: soil, water and life from profile to planet
}

\author{
M. J. Kirkby \\ School of Geography, University of Leeds, Leeds, UK \\ Correspondence to: M. J. Kirkby (m.j.kirkby@leeds.ac.uk) \\ Received: 8 July 2016 - Published in SOIL Discuss.: 11 August 2016 \\ Accepted: 24 November 2016 - Published: 12 December 2016
}

\begin{abstract}
Earth is unique in the combination of abundant liquid water, plate tectonics and life, providing the broad context within which the critical zone exists, as the surface skin of the land. Global differences in the availability of water provide a major control on the balance of processes operating in the soil, allowing the development of environments as diverse as those dominated by organic soils, by salty deserts or by deeply weathered lateritic profiles. Within the critical zone, despite the importance of water, the complexity of its relationships with the soil material continue to provide many fundamental barriers to our improved understanding, at the scales of pore, hillslope and landscape. Water is also a vital resource for the survival of increasing human populations. Intensive agriculture first developed in semi-arid areas where the availability of solar energy could be combined with irrigation water from more humid areas, minimising the problems of weed control with primitive tillage techniques. Today the challenge to feed the world requires improved, and perhaps novel, ways to optimise the combination of solar energy and water at a sustainable economic and environmental cost.
\end{abstract}

\section{Water and critical zone typology}

The earth provides a unique planetary environment in which liquid water, plate tectonics and life have co-evolved to create the critical zone. Many of the interconnected processes are well known, and they are described in greater detail elsewhere (e.g. Jacobson et al., 2000): the present review focusses on the role of water within the soil system. Human existence relies on the properties of this dynamic soil layer and the ways in which water helps to maintain and regenerate the ecosystem services that it provides. Soil properties have been described as depending on climate, biota, relief, parent material and time (Jenny, 1941). Although not explicit in this list, water plays a vital part in almost all soil processes, mediating their dependence on these five factors. In Fig. 1, the factors most directly linked to soil development have been rearranged to show the central role played by water in soil processes (Hillel, 1971). Climate and parent material may be regarded as the most nearly independent external controls on soil development, atmospheric exchanges somewhat less so, while water plays a vital role as an intermediary, especially between climate, biota and soil. The close interdependence of all these processes demands multidisciplinary research (Brevik et al., 2015) to deepen our understanding.

The availability of water depends on the climate, defining the amount of precipitation, its form, seasonality and variability from year to year. Water typically spends months (soil water) to centuries (groundwater) within the critical zone, allowing it to interact effectively with soil and bedrock constituents. The areal distribution and seasonal pattern of rainfall and evapotranspiration are, therefore, the strongest global-scale controls on critical zone development.

Water in the soil provides the essential working fluid for plant growth, being directly involved in photosynthesis and providing turgor, and is vital for all organisms in the soil (Bardgett et al., 2001). The way in which biota interact with and influence the critical zone is strongly linked to the intensity of water circulation through living organisms. Where water is freely available, and potential evapotranspiration is high, biomass is generally high, including both vegetation and soil organisms. Decaying vegetation provides soil organic matter and also provides an important resource for the 


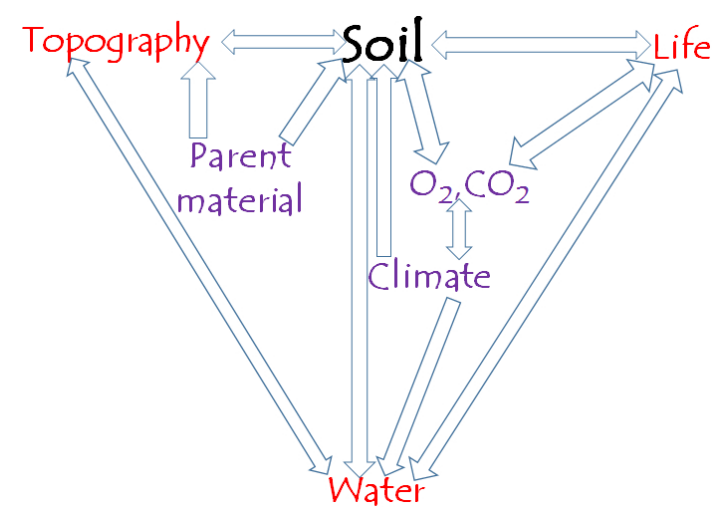

Figure 1. Inter-relationships between soil forming factors, ultimately controlled by parent material and climate, mediated by water, life and topography over a range of time and space scales.

soil organisms that enhance decomposition, as well as a dynamic reservoir for soil water.

Water, acting with gravity, drives many mechanisms that physically move soil grains and aggregates and transport the soil, progressively modifying the topography and, thus, the way in which the critical zone interacts with relief. As relief is progressively lowered, sediment transport is generally reduced, due to the lower potential energy of overland and subsurface flow, whereas chemical removal and water circulation remain important. This trend generally leads to a deeper and more weathered critical zone as relief is lowered, progressively modifying the soil structure and the pathways of water moving over and through the soil, and with organisms actively exploiting the system to their advantage. Within-slope effects are also observed as sediment and organic matter is transferred from upslope to downslope sites, particularly through tillage erosion (e.g. Wright et al., 1990; van Oost et al., 2005).

Water interacts with nutrients and weathering products, and its flow redistributes dissolved material. Water in the parent material acts as solute, dissolving weatherable minerals and making them available for advective transport in flowing water and diffusive transport in immobile water (Kirkby, 1985). In arid conditions, material dissolved from parent material or deposited in the wind is often re-precipitated within the profile as, for example, sodium salts or calcrete. In humid conditions, solutes are largely carried away, progressively weathering the residual soil.

Over time, the critical zone progressively evolves over similar time spans to the evolution of the entire landscape. In some shield areas, this process appears to continue for many tens of millions of years, but, more commonly, the critical zone appears to approach a near-steady state of almost constant mechanical and chemical denudation in which the structure and form of the critical zone is only very slowly changing while the landscape is continuously lowered at a steady rate (Riebe et al., 2003) over time spans of $10^{4}-10^{5}$ years. Until it reaches such a steady state, the critical zone is in a state of transient change, either in response to external shocks such as deforestation and climate change or through the slow evolutionary changes in vegetation. Human population growth and technical development are applying many other stresses that seem to threaten the maintenance of stable earth systems, violating the planetary boundaries within which humanity can safely operate (Steffen et al., 2015). During such periods of transience or instability, many of the most immediate changes in internal processes are strongly driven by changes in soil hydrology.

At a global scale, the dominant control on soil development is the balance between climate and atmospheric inputs. Climate controls the overall soil hydrology, which can be expressed by the relationship between precipitation and potential evapotranspiration. Atmospheric mineral inputs or outputs are partially dependent on the climate. Dust is perhaps the most important single mineral component, source areas being associated with little vegetation cover and at least some dry periods when the surface material can be entrained. Desert areas are the most important source areas, but current and former glacial outwash areas are also significant, currently generating about $10 \%$ of the global dust budget (Bullard, 2013). Areas downwind of source areas receive dust, which is widespread globally but most concentrated close to source areas due to selective transportation of silt-sized material. Particularly high concentrations form the areas of extensive loess accumulation, for example in China, northern Europe and the American Midwest. Other significant atmospheric exchanges are associated with erosion and deposition of inorganic salts that are most concentrated close to the ocean or exposed evaporate deposits (themselves more prevalent in current or former arid areas). The relative importance of atmospheric inputs as agents of soil formation is strongly dependent on the hydrological balance, between precipitation and evapotranspiration (FAO, 1961; Prentice et al., 1992). In Fig. 2, the hydrological balance is compared with the atmospheric exchange balance to define broad regimes of soil development. Where the hydrological balance is very strongly positive (precipitation greater than potential evapotranspiration) throughout the year, organic material accumulates at the surface and persistent waterlogging creates anoxic conditions that minimise decomposition of organic matter, which accumulates as an organic soil. With a less positive and/or more seasonal hydrological balance, the critical zone is dominated by loss of dissolved weathering products and, given sufficient time, develops a deeply weathered profile, often lateritic. Once almost all nutrients have been leached from the upper layers of soil, plants may eventually become largely dependent on atmospheric inputs of nutrients dissolved in rainfall.

Under arid conditions, where the hydrological balance is negative, most of the precipitation that enters the soil is lost in evapotranspiration, redepositing any products of chemical weathering within the soil, most frequently as calcrete layers, 


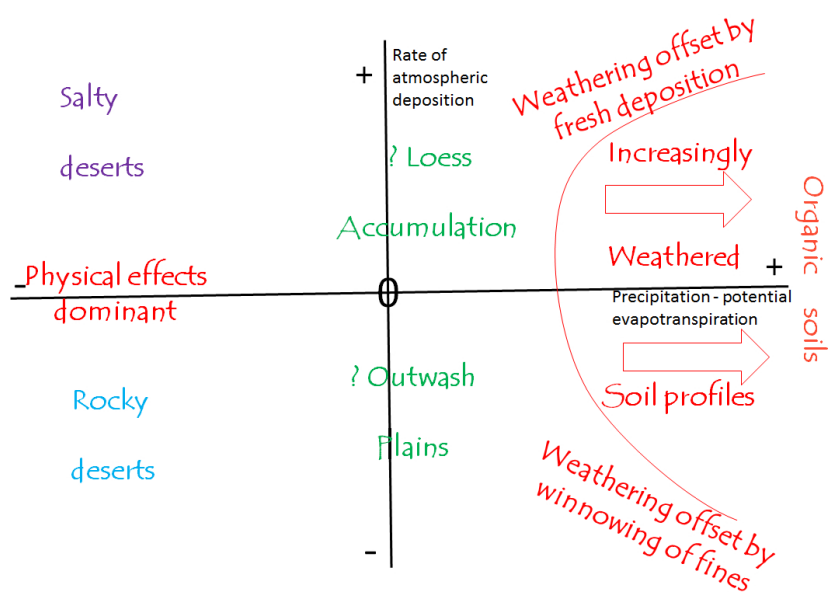

Figure 2. Broad typology of soil types, controlled by net atmospheric inputs (e.g. salt and dust) and net water balance (precipitation minus evapotranspiration).

in some cases increased through inputs of wind-blown dust. Extremely arid areas provide ideal conditions for deflation, and, at the extremes, tend towards a rocky desert from which all fines near the surface have been removed. If, however, there is accumulation of salts, from the sea or from evaporites, then surfaces are instead dominated by salt accumulation and undergo rapid weathering as salts crystallise within the rock (Lavee et al., 1998; Howell, 2009).

Thus, at a global scale, water relations provide the strongest control on evolution of the critical zone. Important differences are, however, also due to the age of soils, for example allowing accumulation of weathering products throughout the Cainozoic in some low-latitude shield areas, and incomplete recycling of material in areas of Pleistocene glaciation. Observed differences also reflect differences in parent materials (e.g. Dere et al., 2010; Vitousek et al., 2016).

Although there are many alternative ways of conceptualising the relationships between water and soil, the development of the critical zone concept has perhaps done more than any other to transform the study of the soil and to emphasise its essentially multidisciplinary nature (Brantley et al., 2007; Lin 2010; Anderson and Anderson, 2010; Anderson et al., 2012; Brevik et al., 2015). Inevitably, some aspects of this refocussing overlap with existing components of earth science; the establishment of critical zone observatories (CZOs), first in the United States (Anderson et al., 2008) and now internationally (Banwart et al., 2012), is doing much to foster new research and improve our understanding of how soil is related to the landscape at hillslope to global scales.

\section{Movement of water within the critical zone}

At finer scales, the relationships between water and soil are in the domain of soil hydrology and soil physics. In both of these fields, there are many questions that are not fully re- solved and, because of their importance, a considerable literature.

At the finest scale, flow of water within the soil is most commonly described by the Richards (1931) equation, restating, for an unsaturated soil, Darcy's (1856) law that the rate of flow is proportional to the pressure gradient. However, the Darcy/Richards approach assumed that as flow passes through the soil, there is complete mixing between the flowing threads of water, and there are commonly substantial deviations from this assumption, because pore sizes and shapes vary, so that water travels faster through macropores when close to saturation, bypassing flow through the finer pores of the soil matrix (Beven and Germann, 1982, 2013; Mooney et al., 1999). Macropores are widespread, due to the contrast in pore sizes between and within individual soil aggregates, as well as more extreme contrasts produced by cracking in clay-rich soils and open pore spaces around stones in the soil. In some cases the behaviour of the soil can be dominated by flow in either the matrix or the macropores, but this response varies with the moisture content as well as over time in swelling soils. In many cases, therefore, a more complex model is required, for example involving dual porosity and marked hysteresis. Experimental evidence is showing the intricate three-dimensional patterns of wetting and draining in a block of soil (e.g. Weiler and Naef, 2003; Haber-Pohlmeier et al., 2009), but, to date, there is no simple model that adequately describes the range of observed behaviours. Simple infiltration equations are still being applied as a necessary phenomenological tool (e.g. Green and Ampt, 1911; Philip 1957, 1969), but it is clear that they can only represent a single prior soil state, for example ponded infiltration into an initially dry soil.

Unsaturated flow in the soil takes place predominantly in the vertical direction, as rainfall percolates toward a saturated level (if there is one) where lateral flow occurs, predominantly in the saturated phase. This contrast reflects the lower hydraulic gradient and the much larger distances involved in lateral flow, so that only saturated flow is able to drive significant volumes of water.

Under climates, and during seasons, where precipitation is less than potential evapotranspiration the movement of water is predominantly vertical: infiltrating water supplies evapotranspiration, only penetrating deeply into the soil in the largest storms, and there is little or no surplus to drive lateral flow. When precipitation exceeds potential evapotranspiration, the excess can only be carried away by lateral flow, which may be overland, within the soil or in groundwater. This dichotomy, often with seasonal switching between these modes (Grayson et al., 1997), shows strong contrasts in the downslope connectivity that is established by lateral flow. In a place and season dominated by vertical fluxes, each point responds independently to the rainfall supply and evapotranspiration demand, and common responses are filtered by local heterogeneities. Lateral connectivity is only briefly established during relatively infrequent flow events, usually over- 
land, so that, in general, behaviour at a point responds only to very local influences. Where lateral flow is dominant, there is a near-continual connection, commonly subsurface, and the hydrological response at any point integrates the effects of every point upslope that drains towards it.

At the soil surface, overland flow is generated either when rainfall exceeds the infiltration capacity (Horton, 1933) or when the surface soil is saturated (Hewlett and Hibbert, 1967; Dunne and Leopold, 1975; Kirkby, 1978; Beven, 2000). The former, infiltration-excess overland flow, is dominant in semi-arid areas where rainfall exceeds potential evapotranspiration so that the soil is dry. Rainfall impact crusts the bare soil surface around the sparse vegetation, while shrubs may funnel water towards their roots (Cammeraat et al., 2010), setting up a strongly contrasting patchwork of infiltration. The latter, saturation-excess overland flow, occurs mainly in humid areas, where rainfall is greater, generating substantial subsurface flow and a strong vegetation cover. However, under many Mediterranean and other seasonal climates, there is switching between these modes during the year and, even in humid areas, and particularly where cultivated fields are bare for part of the year, extreme rainfalls may generate infiltration-excess overland flow. When saturated overland flow occurs, the contributing area commonly expands as saturation builds outward from stream banks and stream-head hollows, driven by concentration of subsurface flow from upslope and the accumulation of rainfall on the nearly saturated ground. Infiltration-excess overland flow, when it occurs, tends to be generated more uniformly, so that flows, when they occur, tend to be more flashy and more damaging. However, there remains a very strong variability in local infiltration capacity, so that, particularly at the beginning of a storm, the detailed pattern of overland flow is characterised by patches of flow generation and re-infiltration which persist until flow becomes general (Kirkby, 2014) and is then dominated by local flow convergence steered by the micro-topography (Fig. 3).

In humid areas, particularly under forest, there is an extensive literature (e.g. Barthold and Woods, 2015) on subsurface flow mechanisms. There appears (Tromp-van Meerveld and McDonnell, 2006) to be strong similarity in many cases between the mechanisms of subsurface flow and those of infiltration-excess overland flow. In each case, rainfall fills depressions and/or infiltration storage and flow begins as these progressively spill over to form connections. The surface for which this process is most critical may be the ground surface (for infiltration-excess overland flow), or a subsurface level below which there is a sharp decrease in permeability, whether due to soil layering or at the soil-bedrock interface. Experimental (e.g. Graham et al., 2010) and modelling data (e.g. Kirkby, 2014; Penuela et al., 2015) support percolation theory (Stauffer and Aharony, 1985; Ali et al., 2013) in finding that the response of such a system to increasing rainfall amounts shows a rather sharp threshold, below which there is negligible flow, and above which there is transition to a near-linear increase in connected flow. Since the sharpness of the threshold varies, it may be best to define the storm size at which $50 \%$ of rainfall runs off as a theoretical threshold.

Two valuable ways of generalising response at the hillslope scale are through the concepts of connectivity (McGuire and McDonnell, 2010: Bracken et al., 2015) and residence time (e.g. Tetzlaff et al., 2010; Bracken and Croke, 2007). At its simplest, connectivity queries the presence or absence of a through-connection between two points. However, it has proved more fruitful for describing the totality of connections from points in an area to an outlet point, and is thereby linked to the runoff coefficient. Connectivity has been widely applied in ecology (McRae et al., 2008) by employing an analogy with electrical conductivity, but the one-way nature of water flow downhill makes this less applicable in hydrology. Instead, the application of percolation theory or the concept of a breakthrough volume to establish connections has proved more applicable, and continues to be developed (Larsen et al., 2012; Janzen and McDonnell, 2015). Residence time is, in a way, the inverse of connectivity, long residence times being associated with poor connectivity for a given reservoir size. The great value of residence time is that its mean value and distribution can be quantified using tracer methods. Perhaps these methods may provide the basis for a better understanding of how water interacts with the critical zone, by focussing on the hillslope rather than the soil profile scale.

Within even a relatively simple soil profile, there are a number of inter-connected reservoirs of water (Fig. 4). Rainwater infiltrates into the soil matrix and in films along the walls of macropores, filling them completely only when the soil is saturated. Further infiltration into the soil matrix takes place along macropore walls. Mainly during storms, some water is able to reach a perched or regional saturated level, above which much saturated lateral subsurface flow is concentrated. Water in the matrix provides the main reservoir for extraction by plant roots as transpiration, newly infiltrated water mixing with water that has already resided in the matrix for many months. Saturated subsurface flow also comes from a reservoir in which old and new water are mixed together (McDonnell, 2014; Kirchner et al., 2000). During a storm, therefore, much of the "new" rainwater is replacing local storages, while much of the slope base outflow consists of older water that is being pushed out. In soil profiles and soil catenas more complex than the cartoon of Fig. 4, and where flood plain deposits abut hillslope catenas, the possible pathways and range of residence times are further increased (Tetzlaff et al., 2010; McGuire and McDonnell, 2010).

Some storm precipitation is not involved in this fill and spill process. Until break-through occurs, all of the rainfall, and after break-through a small fraction, percolates downwards, commonly reaching a level of saturation. Where and when precipitation is of the same order as, or exceeds, potential evapotranspiration, this downward percolation con- 
(a)
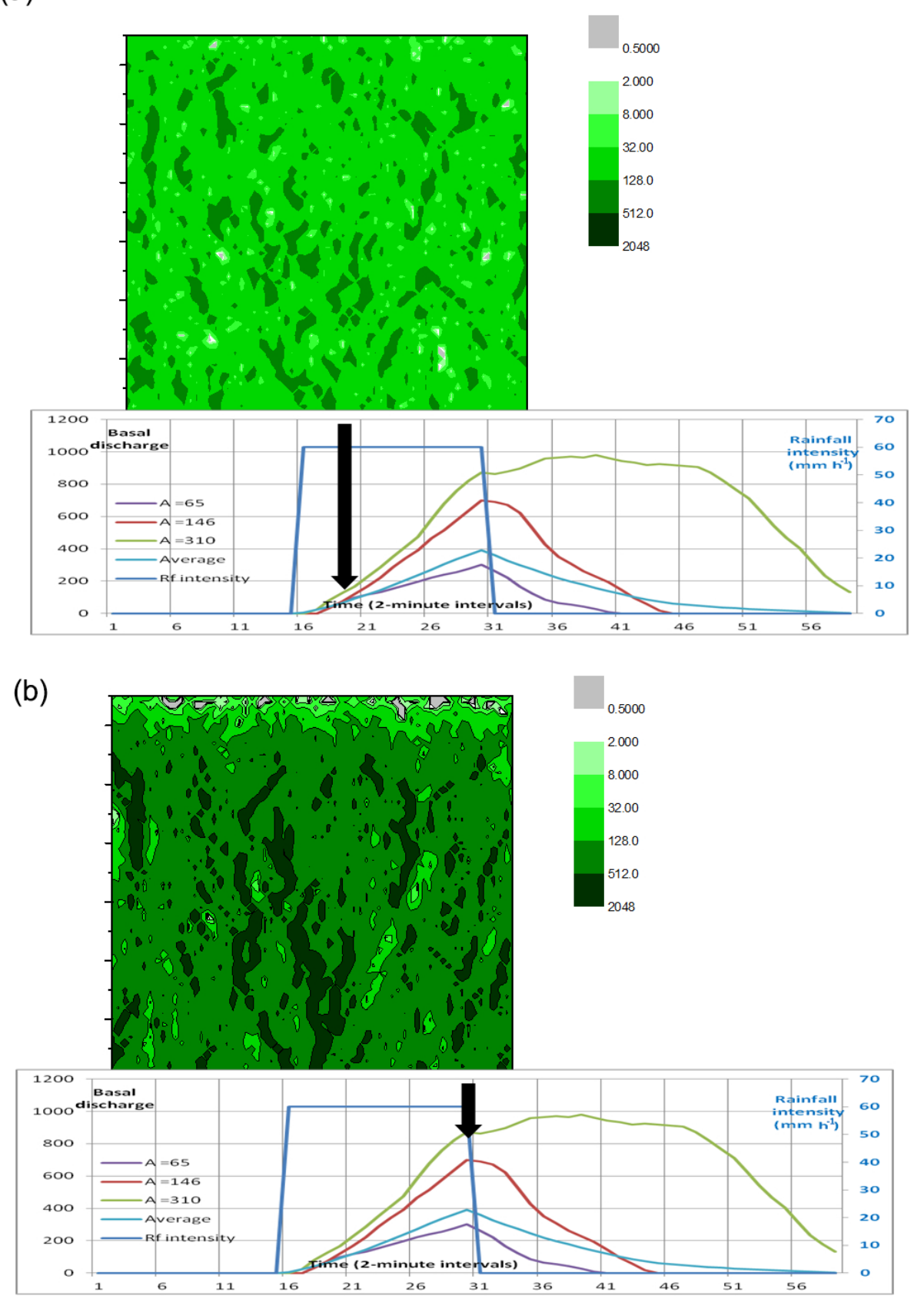

Figure 3. Modelled evolution of runoff patterns on randomly rough slope of $160 \times 160 \mathrm{~m}$. Individual hydrographs are shown for points on the lower boundary with different catchment areas, parts of the total area of $4096(64 \times 64)$. Square shows intensity (on log scale) of local overland flow at a time indicated by the heavy arrows on the hydrographs below. (a) Early in a $30 \mathrm{~mm}$, $30 \mathrm{~min}$ storm, runoff generated in patches of lowest infiltration capacity. (b) As storm rainfall ends, downslope accumulation defines connectivity along strongest flow paths.

tributes to lateral subsurface flow that brings the saturation level progressively closer to the surface in response to flow rates that respond to hillslope plan and profile form: in less humid areas this percolation only occurs in the largest storms, and most water is lost to evapotranspiration. Subsurface flow between and during storms, if it occurs, establishes a dynamically varying saturated area, usually along slope- base concavities and plan-convergent stream heads. Rainfall falling on these saturated areas cannot enter the soil but is immediately diverted as saturation-excess overland flow. The fill and spill level and the saturated subsurface flow level are discussed here as being physically separate, but they may be vertically adjacent, distinct or combined and/or in multiple layers. In many cases, one or other of these mech- 


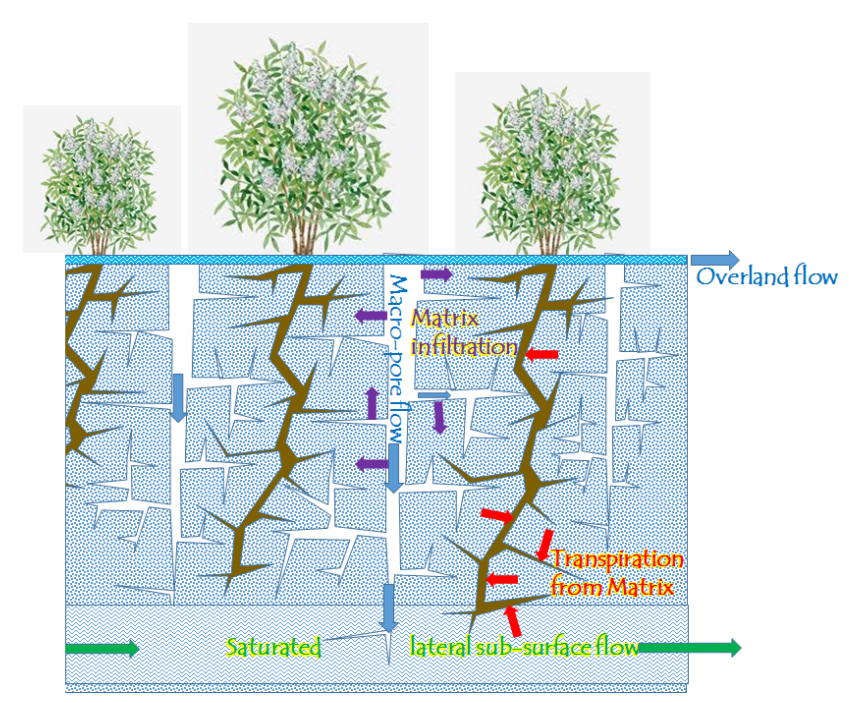

Figure 4. Perceptual model of water flow pathways in the critical zone.

anisms dominates the hydrological response of a hillslope or headwater area (Beven, 2000; Tarboton, 2003). Both fill and spill mechanisms and saturated contributing area mechanisms share a very strong non-linearity in response to storm size, corresponding to the increasing connectivity of flow. At extremes which are rarely achieved, there is $100 \%$ connectivity, but most observations reflect the region of increasing partial connection (e.g. Bracken et al., 2013), although the mechanisms of establishing connected flow differ, with persistent subsurface connection for saturation excess and episodic connection in storms for fill- and spill-dominated systems.

For infiltration-excess overland flow and other fill and spill regimes, connection is typically established dynamically during the course of each individual storm, and decays rapidly afterwards. For saturation-excess regimes, initial connections are established by subsurface flow that persists between storms in areas where precipitation exceeds potential evapotranspiration. The saturated area continues to expand during a storm, and connectivity is only slowly lost, often on a seasonal timescale (Reaney et al., 2014). Over a period, an area may experience fill and spill runoff when storm rainfall exceeds some threshold; at other times, it may experience saturation-excess runoff when net rainfall over a period exceeds another threshold. The fill and spill threshold depends on the structure of vertical storage within the soil, whereas the saturation-excess threshold depends on topographic wetness index and near-surface lateral permeability (Sivapalan et al., 1987; Kirkby et al., 2008). Clearly, semi-arid areas, with little net rainfall, rarely experience saturation-excess runoff, but both mechanisms can co-exist in an area, often with seasonal switching between the two modes (Kirkby et al., 2011).

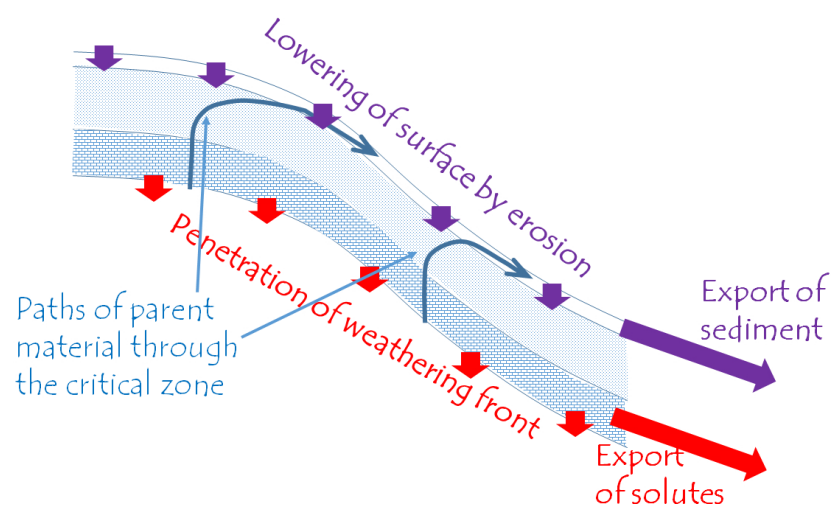

Figure 5. Paths of parent material as it progressively weathers and is carried away as sediment at and near the soil surface. If a steady state develops over time, the rate of surface lowering will be equal to the rate at which the weathering front penetrates into bedrock.

\section{Water as a transporting medium in the critical zone}

As parent material weathers, breaks down into smaller fragments and is eventually removed by erosion at the surface, it passes through the critical zone from bottom to top. Figure 5 sketches the path of grains from the parent material for a steady state in which the critical zone depth remains constant, surface erosion balancing advance of the weathering front. Initially a grain is subjected mainly to chemical weathering, so that it approaches the surface vertically, relative to the downward advancing weathering front. As grains get closer to the surface, they become increasingly influenced by diffusive movements in the soil. These all gradually move material downslope, at a rate that decreases with depth. Eventually, erosion will expose grains at the surface and remove them (Anderson et al., 2002). There is a lateral flux of eroded sediment and weathering products in solution at every point down the length of the hillslope, and, perhaps after intermediate deposition, this material is finally exported at its base, normally to a channel.

Water plays an essential part in these processes, generally percolating less and less with depth where it interacts with rock minerals to release solutes and advance the weathering front (Anderson et al., 2007; Kirkby, 2015). The water is then partly diverted laterally, and partly returned to the surface as evapotranspiration. In semi-arid climates, where potential evapotranspiration exceeds precipitation, there is little lateral movement, and many solutes are redeposited beneath the surface. In more humid climates, lateral flow carries solutes away, and weathering produces a much greater loss of rock substance.

Within the soil, slow diffusive movement is commonly driven by freeze-thaw, wetting-drying and/or bioturbation, and all of these respond positively to the presence of soil water. Where the slope configuration is suitable, larger and more 
rapid mass movements can also move critical zone materials downhill, usually under conditions close to saturation. At the surface, raindrop impact and overland flow drive soil erosion, which is most effective where the surface is not protected by vegetation or stone cover. In all of these ways, the action of water is strongly instrumental in shaping the path followed by grains as they migrate through the critical zone (Fig. 5) and progressively reduce in grain size.

Weathering processes progressively convert strong rock minerals, which have generally been synthesised under high temperatures and pressures in an anoxic environment, to weathering products that are closer to equilibrium with surface conditions and oxygen levels. In this process most minerals lose strength, eventually being converted to granular sand or silt and clay minerals. This loss of strength and reduction in grain size facilitates lateral movement of weathered material close to the soil surface. The balance between chemical (C) and mechanical (M) denudation rates determines the degree of weathering of surface soils. The depletion ratio (Riebe et al., 2003), defined as $\mathrm{C} /(\mathrm{C}+\mathrm{M})$, is a measure of the degree of weathering in the soil, and it generally increases in humid climates (with high C) and decreases where slope gradients are high (with high $\mathrm{M}$ ). Low rates of mechanical denudation reduce stripping of the soil, which then accumulates to greater depth and, in turn, reduces chemical denudation, so that depletion ratios, in any given rock/climate environment, tend towards a stable end-point value.

Water also plays an important role in the carbon and nitrogen cycles that are central to biological activity.

Much of the nitrogen in circulation comes from the application of artificial fertiliser for agriculture, and in deposition around urban areas. Although essential for the increased yields it promotes, it is also one of many organic and inorganic pollutants that reach the soil through direct application and/or in wet and dry deposition (Keesstra et al., 2012). These pollutants or their metabolites play an increasing role in contaminating stream groundwater, with potentially adverse effects on soil organisms and human health (Davidson, 2009).

Overland flow, however generated, is the key agent of soil erosion. Unprotected soil surfaces are impacted by raindrops that break up and detach surface aggregates, packing some down to crust and seal the surface, and ejecting some either into the air (rainsplash) or, where water is already flowing downslope, into the flow (rainflow). Once flow becomes sufficiently strong, due to topographic convergence and/or at high rainfall intensities, the tractive stress exerted directly by the flowing water becomes sufficient to erode the surface and detach material (rillwash). When this happens, the flow begins to incise channels into the surface, thereby increasing the convergence of flow lines in a positive feedback that leads to rilling or gullying. All of these processes are highly size-selective, transporting the finest material farthest from its detachment point, and rates of movement increase with slope gradient (Knapen et al., 2007).
Surfaces may be protected either by vegetation or by stone cover. The crown cover of vegetation breaks the impact of falling raindrops, so that they then strike the ground with low momentum and detach little material (except under highcrowned trees). Stones protect the surface directly, and each stone tends to shield a rim of soil in its immediate shadow, so that it does not become crusted (Poesen et al., 1994; Cerda, 2001). Crusting, particularly in silt-rich soils, is very effective in reducing infiltration and therefore increasing overland flow and, indirectly, erosion. Where the soil is stony, initial erosion tends to winnow out the fine material until the stones, which are less easily carried way, are left behind to armour and partially protect the surface from further erosion. Deep gullying is therefore strongly associated with deep soils that are deficient in stones, either through the action of weathering or as a property of the parent material: thick loess deposits provide an extreme example.

Agricultural fields, at times of year when the surface is almost bare, are generally vulnerable to greater erosion than areas of semi-natural vegetation, particularly so when this period is also one with a high risk of intense rainstorms. During a severe storm, rills generally form with a more or less regular spacing. At the same time as their bed is being incised by the concentrated flow, material is also being delivered to them by rainsplash and rainflow from the intervening areas, so that their downward incision may be self-limiting, often cutting down only to a hardened plough-pan level.

On all but the steepest slopes, slow mass movements, soil erosion by water and chemical denudation are the dominant processes through which hillslopes evolve over time. Under diffusive processes such as soil creep, rainsplash and tillage erosion, hillslope profiles gradually evolve towards a mainly convex form, with a narrower concavity towards the base, as has long been observed (Gilbert, 1877). In steeplands, however, rapid mass movements assume the dominant role, and tend to produce almost rectilinear slopes once cliffs have been eliminated. The much higher rates of sediment transport create a critical zone that generally remains thinner, and with lower chemical depletion ratios than on lower-gradient slopes, even though the shallow soil depth promotes a relatively high rate of chemical denudation (Emberson et al., 2016).

Sediment transport also shapes the three-dimensional landscape geometry, through the interplay of diffusive and advective sediment transport processes. Where advective sediment transport by water is able to evacuate sediment faster than it can be replaced by diffusive processes or mass movement, channels become progressively incised, defining the drainage density of the landscape and thus the average length of hillslope profiles. This is a dynamic process in which major storms are responsible for headward stream extension, and fresh headcuts are partially infilled between major storms, so that the instantaneous stream-head position fluctuates, reflecting recent storm history. Drainage density tends to be higher in more arid climates, reflecting the dom- 
inance of surface flow processes where vegetation is sparse. Density also tends to increase with valley gradient, because advective transport generally increases more than diffusive transport as gradient increases (Montgomery and Dietrich, 1992).

The interplay of hillslope and channel processes responds not only to climatic variability but also to land use changes that modify sediment supply, most strikingly following changes in land use. Where land use change exposes more bare soil, as in deforestation and adoption of arable farming, runoff and sediment load tends to increase. Channel runoff is generally less strongly affected by local changes, so that the increased sediment delivered from side slopes is redeposited along channelways because their transporting capacity is not proportionally increased (Rommens et al., 2005). Contrariwise, afforestation can lead to stream incision (Keesstra, 2007; Sanjuan et al., 2014).

These considerations show that water plays a crucial role in almost all processes acting within the critical zone, and across the full range of landscape scales (Brantley et al., 2007; Anderson et al., 2015). Although other factors, such as lithology and tectonics, also play a very important role, climate, principally acting through the availability and distribution of water, has a dominant influence on the structure and composition of the soil; on the rates and styles of mechanical and chemical denudation; and on the profile form, plan shape and length of hillslope profiles. Many of the processes involved in shaping three-dimensional hillslope form are now being incorporated into successful landscape evolution models (Tucker et al., 2001; Egholm et al., 2013) including the effects of non-linear diffusion (Roering et al., 2001). However, the incorporation of chemical solution in these models perhaps remains their least satisfactory component (Brantley et al., 2007).

\section{Water for plant growth}

Roots grow actively to seek pore water which they require to maintain their turgor against strong capillary tension and to permit photosynthesis. Except where a saturated zone is within reach of their root system, the water that plants use appears to come mainly from the matrix within soil peds, and is substantially separate from the water in cracks and macropores between aggregates that is the main contributor to stream flow (McDonnell, 2014). When water flows through macropores, it also infiltrates into the peds beside each macropore, recharging the soil matrix which then provides a longer-lasting store of water to supply the plants (Germann and Beven, 1985). Water also supports soil microflora, especially fungi, bacteria and viruses, as well as fauna from termites and earthworms to nematodes and protozoa that graze, mainly on bacteria and living plant material or their organic matter residues. Bacteria are important in catalysing weathering processes and, with some fungi (mycorrhiza), support plant growth by fixing atmospheric nitro- gen. The various soil organisms are essential to a healthy soil, and typically contribute up to $5 \%$ of the total organic soil biomass.

It has been argued (Schymanski et al., 2008) that the vegetation cover develops in such a way as to maximise its productivity, and such a principle of optimality may be a way to simplify the complex web of interactions linking vegetation and soil organisms to water use. Most existing models, however, use a more physically based set of constraints to model vegetation and how it may respond to global climate change (e.g. Scheiter et al., 2013).

Matrix water is most frequently available near the soil surface, since macropores are most frequent there and are commonly active with every rainfall event. Roots require water and oxygen and partly mirror this distribution, often with a more or less exponential decay in density with depth. Some plants also develop deep tap roots that can reach down to a water table at $10 \mathrm{~m}$ or greater depths, a strategy favoured by semi-arid phreatophytes that exploit local water tables below ephemeral streams.

Water is probably the most important agent responsible for the structure and processes within the root zone; its presence and distribution, acting through the vegetation and soil organisms, enables the processes of decomposition and bioturbation that dominate these surface layers of the critical zone, and these processes profoundly modifying the soil structure and hydrology.

Plant roots and mesofauna (e.g. earthworms and termites) physically break up the soil, allowing the penetration of air and water. Larger burrowing animals, falling trees and freeze-thaw or wetting-drying cycles can also play a part in breaking up and mixing the near-surface soil. The cumulative action of all these processes can be considered as a diffusive mixing, with a net upward drift of soil material towards the free surface, which is counterbalanced by settling under gravity, significantly assisted by the downward percolation of water (Gabet et al., 2003). Over a few decades, the balance between these processes leads to an equilibrium bulk density profile, in which porosity declines with depth. This bioturbation mixes and homogenises the upper layers of mineral soil, since it occurs much more rapidly than chemical weathering, and may readily be visually distinguished from weathered saprolite, in which original bedrock morphology is preserved in the weathered material.

Organic matter is released from plants, partly as leaf (and stem) fall to accumulate on the surface and partly as in situ root decay. Over decades, this material takes part in the vertical mixing and is also decomposed, gradually releasing $\mathrm{CO}_{2}$ into the soil (Attal et al., 2015; Johnson et al., 2014; Herold et al., 2014). Since the processes of mixing and decomposition occur over similar time spans of decades to centuries, the soil organic matter also develops a vertical distribution within the soil, generally with a smaller-scale depth (tens of centimetres) of exponential decay than for bulk density. Plants also 
modify the chemical environment of the soil, synthesising organic acids that influence water movement and soil $\mathrm{pH}$.

These mixing processes, by modifying the near-surface soil, tend to increase the rate at which water is able to infiltrate, creating a positive feedback in which greater biological activity increases the availability of water in the soil, which in turn encourages biological activity. Eventually, soils are able to absorb the available precipitation so that, over a time span of decades to centuries, there is a feedback tendency for soil structure, and to some extent topography, increasingly to reflect the natural vegetation and to reduce overland flow runoff.

\section{Water as an agricultural and food resource}

By far the greatest consumptive use of water by mankind is for agriculture. An average of approximately $3800 \mathrm{~L}$ a day is needed to support each individual (Hoekstra and Mekonnen, 2012), $92 \%$ of which grows their food. Other major requirements are for domestic use (3.8\%) and for clothing and other industrial products $(4.7 \%)$. These requirements differ in kind, in that domestic water has to be delivered to the individual, whereas for other uses the water can be more economically provided by transporting the food or clothing. However, most countries are also concerned with food security, so that there is some perceived pressure towards being at least partially self-supporting for food production.

Historically, the development of large-scale agriculture has been in semi-arid regions of the Middle East and Mesoamerica, commonly using irrigation water canalised from rivers (Mazoyer and Roudart, 2006). Semi-arid areas have the advantages of providing ample solar energy for photosynthesis, together with relative ease of weed removal. However, irrigation has, historically, commonly led to salinisation of the soil, sometimes irreversible, depending on the quality of the irrigation water and whether sufficient irrigation water has been applied to leach excess salts. Clearance of land in warm humid regions, although providing ample water and solar energy, is hampered by the re-establishment of native weed species and rapid depletion of topsoil nutrients. Long fallow periods (shifting agriculture) were therefore required until modern machinery and fertilisers could be applied. Increasing population pressure may also place pressure on land resources, forcing undesirable reductions in the fallow rotation period. In all areas, seasonal exposure of the bare land surface prior to planting and after harvest exposes the land to increased soil erosion, particularly when rainfall is intense at these critical times of year. In the great majority of cases, arable farming increases the natural rates of soil erosion by water, increasing losses by at least an order of magnitude (Montgomery, 2007) and progressively degrading the land. Water erosion takes some steeper, thin-soil areas out of production and, more widely, removes the most nutritious topsoil and organic material. Cultivation, by exposing the soil surface and allowing it to dry out, can also increase wind erosion in semi-arid areas (e.g. Houyou et al., 2014). In addition, conventional ploughing, whether on the contour or downslope, moves material downslope and generally exposes soil organic matter to more rapid decomposition, reducing the long-term water-holding capacity of the soil. However, because significant deterioration of the soil takes many decades and restoration is also slow, farmers may have little shortterm incentive to improve conservation practices.

Some of the negative effects of agriculture can be mitigated by appropriate management (e.g. Keesstra et al., 2016), but these often require initial and ongoing investment that is not available to all farmers. Some soil conservation measures such as inter-cropping can be applied at low cost, but the majority, including terracing, contour ploughing, residue management, water harvesting, and reduced tillage, require investment and/or some sacrifice of cultivable land area. Management systems that retain a vegetation cover reduce the loss of sediment (Abrahams et al., 1994; Zhao et al., 2016) and organic matter (Gao et al., 2016), even where runoff is not reduced.

As well as on-site management of water resources, there is a global shortage of renewable water resource in the face of increasing populations. There are a number of technical solutions to these problems, for example breeding crops that require less water, irrigating crops as efficiently as possible without incurring the risk of salinisation, and water harvesting. Others, for example large-scale desalinisation of seawater, carry significant costs that cannot readily be accepted by increasing the cost of food to consumers.

The broader implications, for global water needs and for food security, are analysed further in Figs. 6-8 on a countryby-country basis, using data drawn from FAO reports (2000, 2016). In Fig. 6, the population that can be supported by renewable water and potential arable land resources is calculated, using two simplified scenarios. In the first, rain-fed cereal cultivation is assumed, utilising the available average annual water supply from rainfall. For efficient agriculture with good agronomic practice and fertiliser application, the grain yield $Y$ in $\mathrm{kg} \mathrm{ha}^{-1}$ is calculated as

$Y=16.7(E-150)$,

where $E$ is the annual depth of water in millimetres available for plant transpiration, which is assumed equal to precipitation for dry climates (based on Sadras et al., 2011). An upper limit of $8400 \mathrm{~kg} \mathrm{ha}^{-1}$ is assumed, corresponding to a consumptive use of $600 \mathrm{~mm}$ in optimal conditions. However, yields in the western Sahel, and elsewhere where soils are poor and fertiliser is not widely available, are approximately $40 \%$ of the above estimate. In Fig. 6a, estimates of sustainable population are plotted against actual country population. The blue line and left-hand vertical scale refer to efficient agriculture with adequate fertiliser inputs: the red line and right-hand scale refer to low-efficiency agriculture. In each 
case the lines indicate countries with or without adequate resources for self-sufficient rain-fed agriculture. It can be seen that there are a few counties without adequate rainfall, even with efficient agriculture, and a number that may fail without efficient farming practices. In addition, $31 \%$ of the countries for which there are data have less than $150 \mathrm{~mm}$ annual rainfall and therefore do not, on average, have enough water to support any rain-fed farming.

In a second scenario, efficient water harvesting, potentially gathering water from the entire area, is used to concentrate water on as much as possible of the potentially arable land to provide $600 \mathrm{~mm}$ of water and optimum yields on the farmed area. Figure $6 \mathrm{~b}$ shows, with a similar key, that many countries are still short of water, as well as the extent to which efficient farming alleviates this. Figure $6 \mathrm{~b}$ appears to show many more countries with a water deficit than Fig. 6a, but this is because all countries have at least some theoretical water-harvesting potential. Although these simple analyses make the optimistic assumption that water is freely transferrable within a country, it can be seen that there is a lack of sufficient water resources, which is made more severe where yields are low due to a lack of fertiliser and good farming practice. Some continuing increase in world population, together with further deterioration of soil resources due to erosion and salinisation, therefore presents a major challenge for the future.

Figure 7 shows the actual and potential arable land in each country and the average renewable water in each. The horizontal line is set at $600 \mathrm{~mm}$, which is the approximate amount of water required to grow an optimal cereal crop. It can be seen that many countries have not sufficient water to make full use of their presently utilised arable land resources, and that water limitations are a major factor in preventing cultivation of additional potential arable land. Figure 8 shows the renewable water resources per capita for each country, plotted against the population. The upper horizontal line shows the approximate amount of water required to grow food for the population (ca. $1200 \mathrm{~m}^{3}$ per capita per year), and the lower line the amount needed for domestic use $\left(\mathrm{ca} .60 \mathrm{~m}^{3}\right)$. It can be seen that there are many countries that cannot feed themselves, and a smaller number that lack sufficient renewable water to supply domestic needs. Although food needs can be and currently are being partially met by international trade, with implicit water transfers within the food, lack of food security remains a source of potential conflict.

One renewable and low-cost means of increasing available water is through water harvesting. Where rainfall is almost adequate for rain-fed farming, conservation measures may be all that is needed to ensure that storm runoff is retained on-site, in mulch layers, in trenches or behind bunds. As water scarcity increases, an area to be cultivated can be supplied with runoff from a collecting area above and around it, which provides water to the cultivated patch. The required ratio of cultivated area to collecting area can be estimated as the ratio of actual to potential evapotranspiration in a given

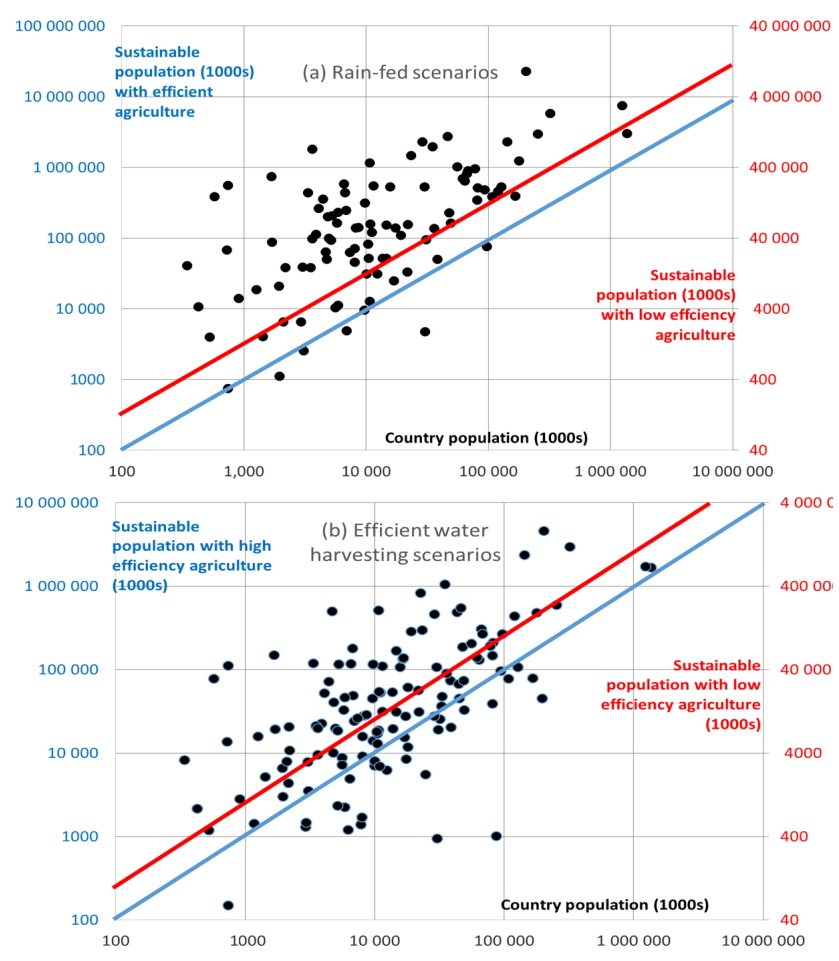

Figure 6. (a) Sustainable population assuming rain-fed agriculture. Left-hand axis is for efficient agriculture; right-hand axis is for low efficiency. Lines show self-sufficiency levels with high- (blue) and low-efficiency (red) farming. (b) Sustainable population if available rainfall is effectively concentrated by water harvesting. Note that some of the countries that appear here had insufficient rainfall for any rain-fed farming. Lines represent levels of full sustainability. The $31 \%$ of countries not shown cannot support any rain-fed agriculture based on their average rainfall.

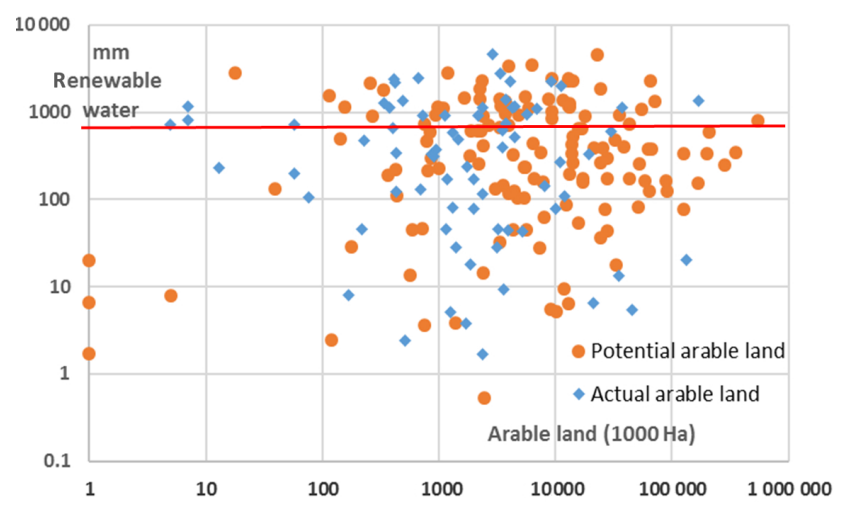

Figure 7. Renewable water resources ( $\mathrm{mm}$ of water per year) and arable land available by country. Diamonds show actual arable land and circles show potential arable land. The horizontal line divides countries with and without enough water to fully utilise their arable land.

region. Analysis of the climate thus gives some idea of where different styles of water harvesting can be applied most effectively. Figure 9 shows, for Africa, the ratio of actual to 


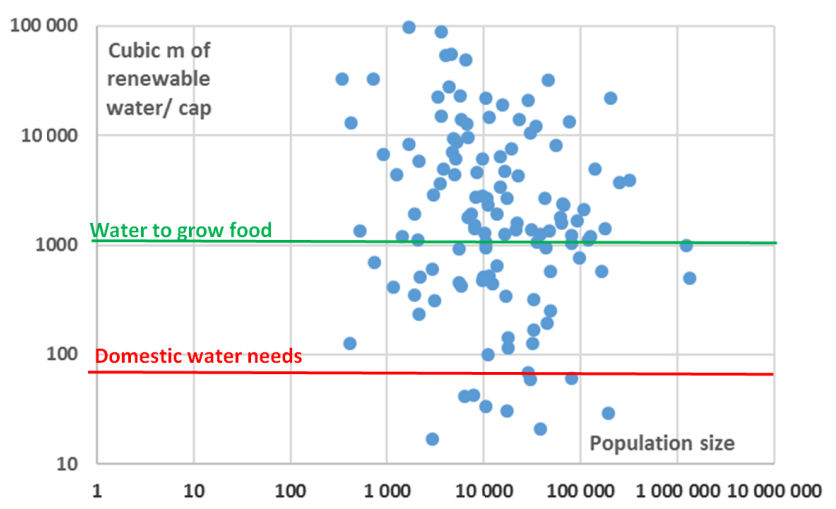

Figure 8. Renewable water per capita against population size by country. The lines the annual water resources needed to grow food (ca. $1200 \mathrm{~m}^{3}$ per capita) and for domestic water supply (a $80 \mathrm{~m}^{3}$ per capita). Many countries do not have enough water to be food-secure, and some lack enough water for domestic use.

potential evapotranspiration for the most suitable 5-month growing season, and for the worst $25 \%$ of annual conditions. Water harvesting can benefit crop yields when this ratio lies between about 0.2 , where ephemeral stream floods can be diverted into fields up to about 1.5 to maximise crop reliability in areas with high inter-annual variability. The ratios of collecting area to irrigated area are the reciprocals of these values, and are generally somewhat larger due to the inefficiencies of collection and redistribution. Where the collecting area is large, runoff collection can be made more efficient by removing stones from the surface to encourage crusting of the soil, and by channelling runoff into discrete runnels to further reduce infiltration losses.

Where the collecting: cropping area ratio is low $(<3)$, an individual group of plants can be supplied by an immediately adjacent patch of bare soil. This gives a pattern of pits where seeds are planted, each surrounded by a small area that drains towards it (zai). At larger scales, a small planted field of, say $10 \times 10 \mathrm{~m}$, may be supplied with water collected from a small upslope mini-catchment (jessour), with perhaps a $20: 1$ ratio of collecting area to irrigated area. At the coarsest scale, these water-harvesting practices (Critchley et al., 1991) merge into regional irrigation systems. Increases in the ratio of collecting area to cultivated area lead to increased yields, but this may be offset by the sacrifice of potential yield from the uncropped area where this is also suitable for arable farming. Part of the net advantage is therefore obtained through greater labour efficiency in farming a smaller area, and the reduced likelihood of crop failure. Figure 10 shows the modelled frequency distribution of estimated yields over a run of years, for Mekelle (northern Ethiopia), with different ratios of collecting to cropping area (CAR). It can be seen that although most years provide some harvest, the median yield and its reliability are greatly enhanced by water harvesting (Fleskens et al., 2016). Reliability can be further increased

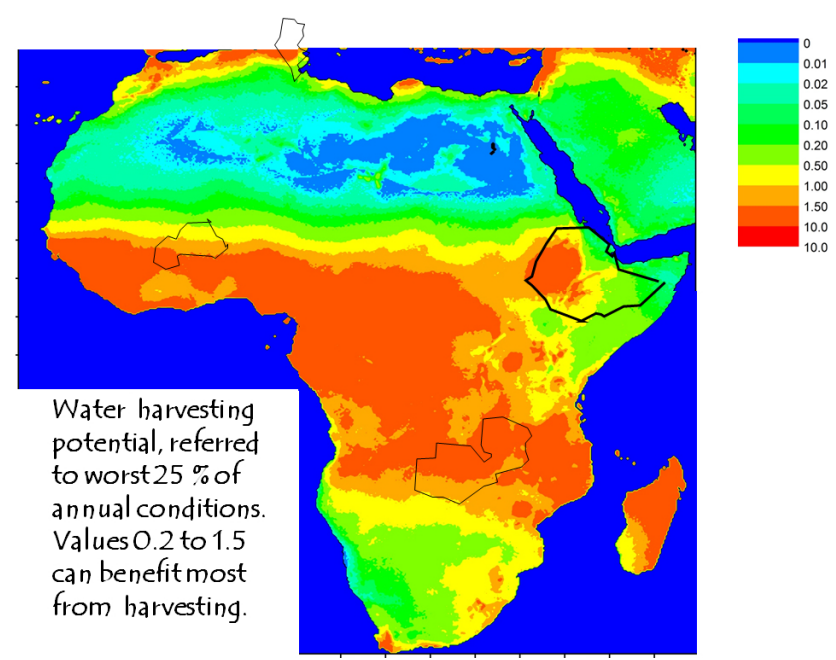

Figure 9. Water harvesting potential in Africa, based on climatic data. The map shows the ratio of precipitation to potential evapotranspiration for a 5-month growing season, for the worst $25 \%$ of years. At values less than 0.2 , water harvesting is only practicable in very favourable situations. Above 1.5 , rain-fed farming generally provides an adequate crop without water harvesting.

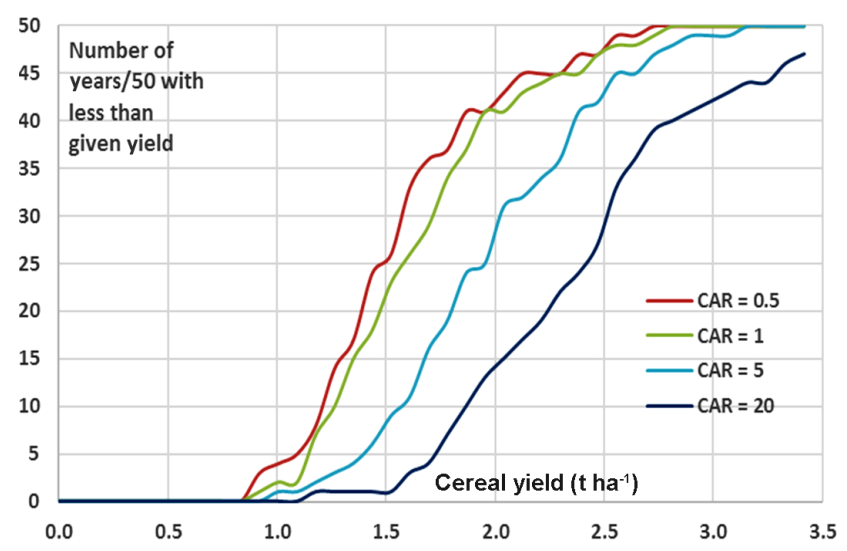

Figure 10. The modelled frequency distribution of crop yields for Mekelle, northern Ethiopia, for a range of ratios of collecting: cropping area (CAR), illustrating the greater reliability of crop yields with effective water harvesting.

by installing ponds that not only collect but also store water, often allowing irrigation in dry spells but subject to evaporative loss.

It is clear that water is a critical resource for agriculture, and will become more so in the future (Falkenberg et al., 2009), particularly because global warming is thought to increase aridity in many water-stressed areas (e.g. Gao and Giorgi, 2008 for the Mediterranean), and because of the interactions with energy production (Pimentel et al., 2004). Figure 11 sketches some of the interactions that need to be managed in order to maintain affordable food production for a still growing world population. Crop production requires 


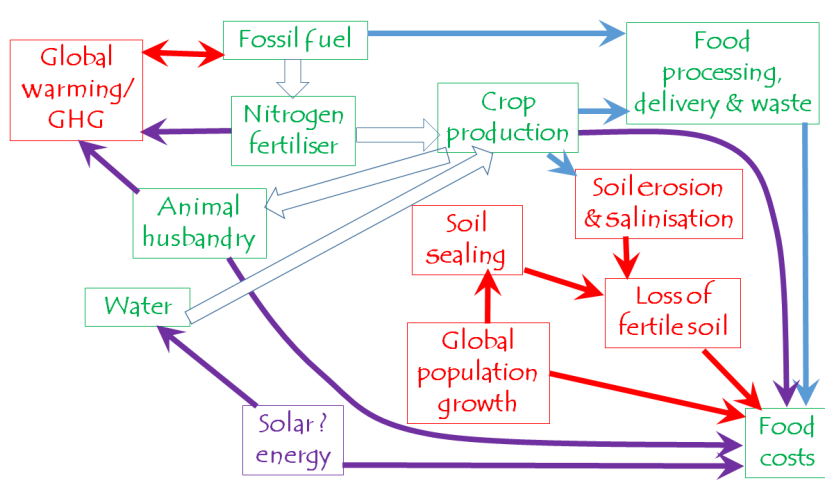

Figure 11. Factors influencing the relationships between water use and the cost of food, taking account of energy needs for fertiliser and possible water desalination, loss of cultivable land and greenhouse gas emissions.

both water and energy, mainly used for the manufacture of nitrogen fertiliser, but also for transportation on the farm and to the market. Widespread use of fertiliser has quadrupled yields since 1900, reducing the dependence of land as a critical resource, but without reducing the need for additional water to support the increased crop yields, so that water has become the most critical resource for further expansion of food production. Nitrogen fertiliser production uses 3-5\% of the world's natural gas as a source of hydrogen, and only a fraction of the nitrogen is used by crops, so that nitrogen is a major source of pollution both directly in runoff, recycled through animal manure, and as a greenhouse gas. Nitrogen in runoff contaminates groundwater and is responsible for eutrophication of lakes and coastal waters.

Although water can be desalinated, the cost of irrigation water produced from seawater its cost is very high in relation to other costs of food production. Typical developed world farm-gate current cereal costs of about USD 200 per tonne (Zimmer, 2012) would be increased by about USD 1000 per tonne for the desalinated water needed to grow the cereal (ca. USD 1 per cubic metre). These costs may be becoming acceptable for domestic water supply and for some high value crops but cannot, at present, be accepted for staple foods or animal husbandry. Although desalination might be supported by renewable energy, for example to irrigate the Sahara, it also generates disposal problems for the salt removed and thus is not environmentally neutral.

\section{Conclusions}

Water is everywhere. Life and mankind would not exist without it. As population continues to grow, fresh water is becoming an increasingly scarce resource. To make the best use of fresh water, most critically for food production, it is vital to share it wisely. One key aspect of this is to progressively improve our knowledge of how water interacts with the critical zone at every time and space scale, and to better recognise and gradually stretch the limits of what is possible. Water and soil present challenges at every scale, from the grain to the globe, and it is a matter of urgency to engage with these issues as best we can, both as practical problems requiring urgent solution and to enhance scientific understanding.

Acknowledgements. Some of the results reported here are based on research in the EU-funded WAHARA project. This project is financed through the EC FP7 ENVIRONMENT programme ENV.2010.3.1.1-4 Water harvesting technologies in Africa (project reference 265570).

Edited by: S. Keesstra

Reviewed by: G. Govers and two anonymous referees

\section{References}

Abrahams, A. D., Parsons, A. J., and Wainwright, J.: Resitstance to overland flow on semiarid grassland and shrubland hillslopes, J. Hydrol., 156, 431-446, doi:10.1016/0022-1694(94)90088-4, 1994.

Ali, G., Oswald, C. J., Spence, C., Cammeraat, E. L. H., McGuire, K. J., Meixner, T., and Reaney, S. M.: Towards a unified threshold-based hydrological theory: necessary components and recurring challenges, Hydrol. Process., 27, 313-318, doi:10.1002/hyp.9560, 2013.

Anderson, R. S. and Anderson, S. P.: Geomorphology: the mechanics and chemistry of landscapes, Cambridge University Press, 651 pp., ISBN: 978052151978, 2010.

Anderson, S. P., Dietrich, W. E., and Brimhall, G. H.: Weathering profiles, mass-balance analysis, and rates of solute loss: Linkages between weathering and erosion in a small, steep catchment, Geol. Soc. Am. Bull., 114, 1143-1158, 2002.

Anderson, S. P., von Blanckenburg, F., and White, A. F.: Physical and chemical controls on the critical zone, Elements, 3, 315-319, doi:10.2113/gselements.3.5.315, 2007.

Anderson, S. P., Bales, R. C., and Duffy, C. J.: Critical Zone Observatories: Building a network to advance interdisciplinary study of Earth surface processes, Mineralogical Magazine, 72, 7-10, doi:10.1180/minmag.2008.072.1.7, 2008.

Anderson, S. P., Anderson, R. S., and Tucker, G. E.: Landscape scale linkages in critical zone evolution, Comptes Rendus Geoscience, 344, 586-596, doi:10.1016/j.crte.2012.10.008, 2012.

Anderson, S. P., Foster, M. A., Anderson, S. W., Dühnforth, M., and Anderson, R. S.: Putting weathering into a landscape context: Variations in exhumation rates across the Colorado Front Range, EGU General Assembly Conference Abstracts, 17, 7992, 2015.

Attal, M., Mudd, S. M., Hurst, M. D., Weinman, B., Yoo, K., and Naylor, M.: Impact of change in erosion rate and landscape steepness on hillslope and fluvial sediments grain size in the Feather River basin (Sierra Nevada, California), Earth Surf. Dynam., 3, 201-222, doi:10.5194/esurf-3-201-2015, 2015.

Banwart, S., Manoj Menon, M., Bernasconi, S. M., Bloem, J., Blum, W. E. H., Maia de Souza, D., Davidsdotir, B., Duffy, C., Lair, G. J., Kram, P., Lamacova, A., Lundin, L., Nikolaidis, N. P., Novak, M., Panagos, P., Vala Ragnarsdottir, K., Robinson, D., Rousseva, S, de Ruiter, P., van Gaans, P., Weng, L., White, T., 
and Zhang, B.: Soil processes and functions across an international network of Critical Zone Observatories: Introduction to experimental methods and initial results, Comptes Rendus - Geoscience, 344, 758-772, doi:10.1016/j.crte.2012.10.007, 2012.

Bardgett, R., Anderson, J., Behan-Pelletier, V., Brussaard, L., Coleman, D., Ettema, C., Moldenke, A., Schimel, J., and Wall, D.: The influence of soil biodiversity on hydrological pathways and the transfer of materials between terrestrial and aquatic ecosystems, Ecosystems, 4, 421-429, doi:10.1007/s10021-001-0020-5, 2001.

Barthold, F. K. and Woods, R. A.: Stormflow generation: A metaanalysis of field evidence from small, forested catchments, Water Resour. Res., 51, 3730-3753, doi:10.1002/2014WR016221, 2015.

Beven, K. J.: Rainfall Runoff Modelling: The Primer, John Wiley, Chichester, ISBN: 978-0-470-71459-1, 2000.

Beven, K. and Germann, P.: Macropores and water flow in soils, Water Resour. Res., 18, 1311-1325, doi:10.1029/WR018i005p01311, 1982.

Beven, K. and Germann, P.: Macropores and water flow in soils revisited, Water Resour. Res., 49, 3071-3092, doi:10.1002/wrcr.20156, 2013.

Bracken, L. J. and Croke, J.: The concept of hydrological connectivity and its contribution to understanding runoffdominated geomorphic systems, Hydrol. Process., 21, 17491763, doi:10.1002/hyp.6313, 2007.

Bracken, L. J., Wainwright, J., Ali, G. A., Tetzlaff, D., Smith, M. W., Reaney, S. M., and Roy, A. G.: Concepts of hydrological connectivity: Research approaches, pathways and future agendas, EarthSci. Rev., 119, 17-34, doi:10.1016/j.earscirev.2013.02.001, 2013.

Bracken, L. J., Turnbull, L., Wainwright, J., and Bogaart, P.: Sediment connectivity: a framework for understanding sediment transfer at multiple scales, Earth Surf. Proc. Land., 40, 177-188, doi:10.1002/esp.3635, 2015.

Brantley, S. L., Goldhaber, M. B., and Vala Ragnarsdottir, K.: Crossing Disciplines and Scales to Understand the Critical Zone, Elements, 3, 307-314, doi:10.2113/gselements.3.5.307, 2007.

Brevik, E. C., Cerdà, A., Mataix-Solera, J., Pereg, L., Quinton, J. N., Six, J., and Van Oost, K.: The interdisciplinary nature of SOIL, SOIL, 1, 117-129, doi:10.5194/soil-1-117-2015, 2015.

Bullard, J. E.: Contemporary glacigenic contributions to the dust cycle, Earth Surf. Proc. Land., 38, 71-89, doi:10.1002/esp.3315, 2013.

Cammeraat, E. L. H., Cerda, A., and Imeson, A. C.: Ecohydrological adaptation of soils following land abandonment in a semi-arid environment, Ecohydrology, 3, 421-430, 2010.

Cerda, A.: Effects of rock fragment cover on soil infiltration, interrill runoff and erosion, Eur. J. Soil Sci., 52, 59-68, doi:10.1002/eco.161, 2001.

Critchley, W., Siegert, K., and Chapman, C.: Water Harvesting: a manual for the design and construction of water harvesting schemes for plant production, FAO, Rome, 1991.

Darcy, H.: Les Fontaines Publiques de la Ville de Dijon, Dalmont, Paris, 647 pp., 1856.

Davidson, E. A.: The contribution of manure and fertilizer nitrogen to atmospheric nitrous oxide since 1860, Nature Geosci., 2, 659662, doi:10.1038/ngeo608, 2009.
Dere, A., White, T., Jin, L., Harbor, D., Townsend, M., and Brantley, S. L.: Shale weathering rates across a continental-scale climosequence, Geography and Geology Faculty Proceedings \& Presentations, Paper 1, available at: http://digitalcommons.unomaha. edu/geoggeolfacproc/1 (last access: December 2016), 2010.

Dunne, T. and Leopold, L. B.: Water in Environmental Planning, W H Freeman and Co, San Francisco, 818 pp., ISBN-10: 0716700794, 1978.

Egholm, D. L., Knudsen, M. F., and Sandiford, M.: Lifespan of mountain ranges scaled by feedbacks between landsliding and erosion by rivers, Nature, 498, 475-480, doi:10.1038/nature12218, 2013.

Emberson, R., Hovius, N., Galy, A., and Marc, O.: Chemical weathering in active mountain belts controlled by stochastic bedrock landsliding, Nature Geosci., 9, 42-45, doi:10.1038/NGEO2600, 2016.

Falkenberg, M., Rockstrom, J., and Karlberg, L.: Present and future water requirements for feeding humanity, Food Security, 1, 5969, doi:10.1007/s12571-008-0003-x, 2009.

FAO: The Digitized Soil Map of the World. World Soil Resources Report 67, FAO Rome, 1961.

FAO: Land and Water Development Division, Land Resource Potential and Constraints at Regional and Country Levels, based on the work of A. J. Bot, F. O. Nachtergaele and A. Young, 114 pp., FAO, Rome, 2000.

FAO, IFAD and WFP: The State of Food Insecurity in the World 2015, Meeting the 2015 international hunger targets: taking stock of uneven progress, Rome, FAO, 2015.

FAO: AQUASTAT Main Database, Food and Agriculture Organization of the United Nations (FAO), available at: http://www.fao. org/nr/water/aquastat/data/query/index.html (last access: June 2016), 2016.

Fleskens, L., Kirkby, M. J., and Irvine, B. J.: The PESERADESMICE Modeling Framework for Spatial Assessment of the Physical Impact and Economic Viability of Land Degradation Mitigation Technologies, Frontiers in Environmental Science, 4, doi:10.3389/fenvs.2016.00031, 2016.

Gabet, E. J., Reichman, O. J., and Seabloom, E. W.: The Effects of Bioturbation on Soil Processes and Sediment Transport, Ann. Rev. Earth Planet. Sci., 31, 249-273, doi:10.1146/annurev.earth.31.100901.141314, 2003.

Gao, X. and Giorgi, F.: Increased aridity in the Mediterranean region under greenhouse gas forcing estimated from high resolution simulations with a regional climate model, Global Planet. Change, 62, 195-209, doi:10.1016/j.gloplacha.2008.02.002, 2008.

Gao, Y., Dang, X., Yu, Y., Li, Y., Liu, Y., and Wang, J.: Effects of Tillage Methods on Soil Carbon and Wind Erosion, Land Degrad. Develop., 27, 583-591, doi:10.1002/ldr.2404, 2016.

Germann, P. F. and Beven, K. J.: Kinematic Wave Approximation to Infiltration into Soils with Sorbing Macropores, Water Resour. Res., 21, 990-996, doi:10.1029/WR021i007p00990, 1985.

Gilbert, G. K.: The Geology of the Henry Mountains, US Geographical and Geological Survey, Washington DC, 1877.

Graham, C. B., Woods, R. A., and McDonnell, J. J.: Hillslope threshold response to rainfall (1): a field based forensic approach, J. Hydrol., 393, 65-76, doi:10.1016/j.jhydrol.2009.12.015, 2010.

Grayson, R. B., Western, A. W., Chiew, F. H. S., and Bloschl, G.: Preferred states in spatial soil moisture patterns: Local 
and nonlocal controls, Water Resour. Res., 33, 2897-2908, doi:10.1029/97WR02174, 1997.

Green, W. H. and Ampt, G.: Studies of soil physics, part I - the flow of air and water through soils, J. Ag. Sci., 4, 1-24, 1911.

Haber-Pohlmeier, S., Bechtold, M., Stapf, S., and Pohlmeier, A.: Water Flow Monitored by Tracer Transport in Natural Porous Media Using Magnetic Resonance Imaging, Vadose Zone J., 9, 835-845, doi:10.2136/vzj2009.0177, 2009.

Herold, N., Schöning, I., Michalzik, B., and Schrumpf, M.: Controls on soil carbon storage and turnover in German landscapes, Biogeochemistry, 119, 435-451, 2014.

Hewlett, J. D. and Hibbert, J. R.: Factors Affecting the Response of Small Watersheds to Precipitation in Humid Areas, in: Forest Hydrology, edited by: Sopper, W. E. and Lull, H. W., Pergamon Press, New York, 275-291 reprinted 2009: Progress in Physical Geography, doi:10.1177/0309133309338118, 1967.

Hillel, D.: Soil and Water, Academic press, 288 pp., 1971.

Hoekstra, A. Y. and Mekonnen, M. M.: The water footprint of humanity, P. Natl. Acad. Sci., 109, 3232-3237, doi:10.1073/pnas.1109936109, 2012.

Horton, R. E.: The role of infiltration in the hydrologic cycle, Transactions, American Geophysical Union, 14, 446-460, 1933.

Houyou, Z., Bielders, C. L., Benhorma, H. A., Dellal, A., and Boutemdjet, A.: Evidence of strong land degradation by wind erosion as a result of rainfed cropping in the Algerian steppe: A case study at Laghouat, Land Degradation and Development, 27, 1788-1796, doi:10.1002/ldr.2295, 2014.

Howell, M. S.: Mineralogy and micromorphology of an Atacama Desert soil, Chile: A model for hyperarid pedogenesis, University of Nevada, Las Vegas Theses, Dissertations, Professional Papers, and Capstones, Paper 52, 2009.

Jacobson, M. C., Charlson, R. J., Rodhe, H., and Orians, G. H.: Earth System Science: From Biogeochemical Cycles to Global Changes, International Geophysics Series 72, Elsevier, 526 pp., 2000.

Janzen, D. and McDonell, J. J.: A stochastic approach to modelling and understanding hillslope runoff connectivity dynamics, Ecol. Modell., 298, 64-74, 2015.

Jenny, H.: Factors of soil formation: a system of quantitative pedology, McGraw Hill, 281 pp., 1941.

Johnson, J. O., Mudd, S. M., Pillans, B., Spooner, N. A., Fifield, L. K., Kirkby, M. J., and Gloor, M.: Quantifying the rate and depth dependence of bioturbation based on optically-stimulated luminescence (OSL) dates and meteoric ${ }^{10} \mathrm{Be}$, Earth Surf. Proc. Land., 39, 1188-1196, 2014.

Keesstra, S. D.: Impact of natural reforestation on floodplain sedimentation in the Dragonja valley, Slovenia, Earth Surf. Proc. Land., 32, 49-65, doi:10.1002/esp.1360, 2007.

Keesstra, S. D., Geissen, V., Mosse, K., Piiranen, S., Scudiero, E., Leistra, M., and van Schaik, L.: Soil as a filter for groundwater quality, Current Opinion on Environmental Sustainability, 4, 507-516, 2012.

Keesstra, S. D., Bouma, J., Wallinga, J., Jansen, B., Mol, G., Munoz-Rojas, M., Nunes, J. P., and Montanarealla, L. (Eds.): Soil Science in a changing world:contributions of soil science for solving global challenges of our time, Soil, Special Issue, available at: http://www.soil-journal.net/special_issue823.html, 2016.
Kirchner, J. W., Feng, X., and Neal, C.: Fractal stream chemistry and its implications for contaminant transport in catchments, Nature, 403, 524-527, doi:10.1038/35000537, 2000.

Kirkby, M. J. (Ed.): Hillslope Hydrology, John Wiley, Chichester, 389 pp., ISBN: 978-0-471-99510-4, 1978.

Kirkby, M. J.: The basis for soil profile modelling in a geomorphic context, J. Soil Sci., 36, 97-121, 1985.

Kirkby, M. J.: Do not only connect: a model of infiltration-excess overland flow based on simulation, Earth Surf. Pro. Land., 39, 952-963, doi:10.1002/esp.3556, 2014.

Kirkby, M. J.: Modelling Soil Profiles In Their Landscape Context, Oral presentation \& Abstract at AGU fall conference, San Francisco, 2015.

Kirkby, M. J., Irvine, B. J., Jones, R. J. A., Govers, G., and the PESERA team: The PESERA coarse scale erosion model for Europe: I - Model rationale and implementation, Eur. J. Soil Sci., 59, 1293-1306, doi:10.1111/j.1365-2389.2008.01072.x, 2008.

Kirkby, M. J., Gallart, F., Kjeldsen, T. R., Irvine, B. J., Froebrich, J., Lo Porto, A., De Girolamo, A., and the MIRAGE team: Classifying low flow hydrological regimes at a regional scale, Hydrol. Earth Syst. Sci., 15, 3741-3750, doi:10.5194/hess-15-37412011, 2011.

Knapen, A., Poesen, J., Govers, G., Gyssels, G., and Nachtergaele, J.: Resistance of soils to concentrated flow erosion: A review, Earth Sci. Rev. 80, 75-109, 2007.

Larsen, L. G., Choi, J., Nungesser, M. K., and Harvey, J. W.: Directional connectivity in hydrology and ecology, Ecol. Appl., 22, 2204-2220, 2012.

Lavee, H., Imeson, A. C., and Sarah, P.: The impact of climate change on geomorphology and desertification along a mediterranean-arid transect, Land Degrad. Develop., 9, 407422, doi:10.1002/(SICI)1099-145X(199809/10)9:5<407::AIDLDR302>3.0.CO;2-6, 1998.

Lin, H.: Earth's Critical Zone and hydropedology: concepts, characteristics, and advances, Hydrol. Earth Syst. Sci., 14, 25-45, doi:10.5194/hess-14-25-2010, 2010.

McDonnell, J. J.: The two water worlds hypothesis: ecohydrological separation of water between streams and trees? Wiley Interdiciplinary reviews: Water, 1, 323-329, 2014.

McGuire, K. J. and McDonnell, J. J.: Hydrological connectivity of hillslopes and streams: Characteristic time scales and nonlinearities, Water Resour. Res., 26, W10543, doi:10.1029/2010WR009341, 2010.

McRae, B. H., Dickson, B. G., Keitt, T. H., and Shah, V. B.: Using circuit theory to model connectivity in ecology, evolution, and conservation, Ecology, 89, 2712-2724, doi:10.1890/07-1861.1, 2008.

Mazoyer, M. and Roudart, L.: A History of World Agriculture: From the Neolithic Age to the Current Crisis (English Translation), Monthly Review Press, 496 pp., ISBN-13: 9781583671214, 2006.

Montgomery, D. R.: Soil erosion and agricultural sustainability, P. Natl. Acad. Sci., 104, 13268-13272, doi:10.1073/pnas.0611508104, 2007.

Montgomery, D. R. and Dietrich, W. E.: Channel initiation and the problme ofl andscape scale, Science, 255, 826-830, doi:10.1126/science.255.5046.826, 1992.

Mooney, S. J., Holden, N., Ward, S., and Collins, J. F.: Morphological observations of dye tracer infiltration and by- 
pass flow in milled peat, Plant and Soil, 208, 167-178, doi:10.1023/A:1004538207229, 1999.

Penuela, F. A., Javaux, M., and Bielders, C.: How do slope and surface roughness affect plot-scale overland flow connectivity?, J. Hydrol., 528, 192-205, doi:10.1016/j.jhydrol.2015.06.031, 2015.

Philip, J. R.: The Theory of Infiltration: Sorptivity and Algebraic Infiltration Equation, Soil Sci., 84, 257-264, 1957.

Philip, J. R.: Theory of infiltration, Adv. Hydrosci., 5, 215-296, 1969.

Pimentel, D., Berger, B., Filiberto, D., Newton, M., Wolfe, B., Karabinakis, E., Clark, S., Poon, E., Abbett, E., and Nandagopal, S.: Water resources: Agricultural and environmental issues, Bioscience, 54, 909-918, doi:10.1641/00063568(2004)054[0909:WRAAEI]2.0.CO;2, 2004.

Poesen, J. W., Torri, D., and Bunte, K.: Effects of rock fragments on soil erosion by water at different spatial scales: a review, Catena, 23, 141-166, doi:10.1016/0341-8162(94)90058-2, 1994.

Prentice, I. C., Cramer, W. Harrison, S. P., Leemans, R., Monserud, R. A., and Solomon, A. M.: A Global Biome Model Based on Plant Physiology and Dominance, Soil Properties and Climate, J. Biogeogr., 19,117-134, doi:10.2307/2845499, 1992.

Reaney, S. M., Bracken, L. J., and Kirkby, M. J.: The importance of surface controls on overland flow connectivity in semi-arid environments: results from a numerical experimental approach, Hydrol. Process., 28, 2116-2128, doi:10.1002/hyp.9769, 2014.

Richards, L. A.: Capillary conduction of liquids through porous mediums, Physics, 1, 318-333, 1931.

Riebe, C. S, Kirchner, J. W., and Finkel, R. C.: Long-term rates of chemical weathering and physical erosion from cosmogenic nuclides and geochemical mass balance, Geochim. Cosmochim. Acta, 67, 4411-4427, doi:10.1016/S0016-7037(03)00382-X, 2003.

Roering, J. J., Kirchner, J. W., and Dietrich, W. E.: Hillslope evolution by nonlinear slope-dependent transport: Steady-state morphology and equilibrium adjustment timescales, J. Geophys. Res., 106, 16499-16513, doi:10.1029/2002JB001822, 2001.

Rommens, T., Verstraeten, G., Poesen, J., Govers, G., van Rompaey, A., Peeters, I., and Lang, A.: Soil erosion and sediment deposition in the Belgian loess belt during the Holocene: establishing a sediment budget for a small agicultural catchment, The Holocene, 15, 1032-1043, doi:10.1191/0959683605hl876ra, 2005.

Sadras, V., Grassini, P., and Steduto, P.: Status of water use efficiency of main crops, in: The state of world's land and water resources for food and agriculture (SOLAW), FAO, Rome and Earthscan, London, 2011.

Sanjuan, Y., Gomez-Vilar, A., Nadal-Romero, E., AlvarezMartinez, J., Arnaez, J., Serrano-Muela, M. P., Rubiales, J. M., Gonzalez-Samperiz, P., and Garcia-Ruiz, J. M.: Linking land cover changes in the Sub-Alpins and Montane belts to changes in a torrential river, Land Degrad. Develop., 27, 179189, doi:10.1002/ldr.2294, 2014.

Scheiter, S., Langan, L., and Higgins, S. I.: Next-generation dynamic global vegetation models: learning from community ecology, New Phytol., 198, 957-969, doi:10.1111/nph.12210, 2013.
Schymanski, S. J., Sivapalan, M., Roderick, M. L., Beringer, J., and Hutley, L. B.: An optimality-based model of the coupled soil moisture and root dynamics, Hydrol. Earth Syst. Sci., 12, 913932, doi:10.5194/hess-12-913-2008, 2008.

Sivapalan, M., Beven, K., and Wood, E. F.: On hydrologic similarity: 2. A scaled model of storm runoff production, Water Resour. Res., 23, 2266-2278, doi:10.1029/WR023i012p02266, 1987.

Stauffer, D. and Aharony, A.: Introduction to percolation theory, Taylor and Francis, London, 193 pp., 1985.

Steffen, W., Richardson, K., Rockstrom, J., Cornell, S. E., Fetzer, I., Bennett, E. M., Biggs, R., Carpenter, S. R., de Vries, W., de Wit, C. A., Folke, C., Gertem, D., Heinke, J., Mace, G. M., Persson, L. M., Ramanathan, V., Reyers, B., and Sorlin, S.: Planetary boundaries: Guiding human development on a changing planet, Science, 347, doi:10.1126/science.1259855, 2015.

Tarboton, D. G.: Rainfall-runoff processes, Technical report, Utah State University, 2003.

Tetzlaff, D., Soulsby, C., and Birkel, C.: Hydrological connectivity and microbiological fluxes in montane catchments: the role of seasonality and climatic variability, Hydrol. Process., 24, 12311235, doi:10.1002/hyp.7680, 2010.

Tromp-van Meerveld, H. J. and McDonnell, J. J.: Threshold relations in subsurface stormflow 2: The fill and spill hypothesis: an explanation for observed threshold behavior in subsurface stormflow, Water Resour. Res., 42, W02411, doi:10.1029/2004WR003800, 2006.

Tucker, G. E., Lancaster, S., Gasparini, N., and Bras, R.: Top of Form The channel-hillslope integrated landscape development model (CHILD), in: Book Landscape erosion and evolution modelling, edited by: Harmon, R. S. and Doe III, W. W., Kluwer Academic/ Plenum, NY, 349-388, ISBN 0-306-46718-6, 2001.

Van Oost, K., Govers, G., Quine, T. A., Heckrath, G., Olesen, J. E., De Gryze, S., and Merckx, R.: Landscape-scale modeling of carbon cycling under the impact of soil redistribution: The role of tillage erosion, Global Biogeochem. Cy., 19, GB4014, doi:10.1029/2005GB002471, 2005.

Vitousek, P., Dixon, J. L., and Chadwick, O. A.: Parent material and pedogenic thresholds: observations and a simple model 2016, Biogeochemistry, 130, 147-157, doi:10.1007/s10533-016-0249$\mathrm{x}, 2016$.

Weiler, M. and Naef, F.: An Experimental Tracer Study of the Role of Macropores in Infiltration in Grassland Soils, Hydrol. Process., 17, 477-493, doi:10.1002/hyp.1136, 2003.

Wright, R. J., Boyer, D. G., Winant, W. M., and Perry, H. D.: The influence of soil factors on yield differences among landscape positions in an Appalachian cornfield, Soil Sci., 149, 375-382, doi:10.1097/00010694-199006000-00009, 1990.

Zhao, C., Gao, J., Huang, Y., Wang, G., and Zhang, M.: Effects of Vegetation Stems on Hydraulics of Overland Flow Under Varying Water Discharges, Land Degrad. Develop., 27, 748-757, doi:10.1002/ldr.2423, 2016.

Zimmer, Y.: Production Cost in the EU and in Third Countries: past Trends, Structures and Levels, Workshop on the Outlook for EU Agriculture by COPA, COGECA, European Crop Protection \& Fertilizers Europe, Brussels, 2012. 